\title{
Identification of methanol-regulated promoter sequences from the facultative methylotrophic bacterium Methylobacterium organophilum XX
}

\author{
H. Howard Xu, Mareike Viebahn and Richard S. Hanson* \\ Department of Microbiology, Gray Freshwater Biological Institute, University of Minnesota, PO Box 100, Navarre, \\ MN 55392, USA
}

(Received 21 August 1992; revised 18 November 1992; accepted 8 December 1992)

\begin{abstract}
A promoter-probe vector (pHX200) was constructed using the broad-host-range cosmid pLA2917 and a promoterless $x y l E$ gene of Pseudomonas as the reporter gene. Insertion of the cloned promoter fragment of the methanol dehydrogenase large subunit gene moxF (methanol oxidation) in front of the $x y l E$ gene in pHX200V47 resulted in high-level expression of the $x y l E$ gene product - catechol 2,3-dioxygenase - in Methylobacterium organophilum XX. The specific activity of the enzyme was four times higher in methanol-grown $M$. organophilum XX culture than in succinate-grown culture. Interestingly, the insertion of the same fragment in the opposite orientation in front of the $x y l E$ gene (pHX200V-74) also led to elevated catechol 2,3-dioxygenase activity. This promoter activity was also methanol regulated. A total of 21 methanol-regulated promoter clones were identified that originate from three gene clusters (groups V, VI and VII) on the M. organophilum XX chromosome involved in methanol oxidation. Vector pHX200 and its derivatives were successfully mobilized into cells of three phylogenetically diverse methylotrophic bacteria: Methylophilus methylotrophus AS1, Methylobacterium extorquens AM1 and Methylobacterium sp. DM4. The reporter gene ( $x y l E)$ was functionally expressed in all three bacteria with the aid of a proper promoter. Transcriptional fusions of methanol-regulated promoters with the $x y l E$ gene were mobilized into Mox mutants of $M$. organophilum XX and M. extorquens AM1 to study the roles of methanol oxidation genes, especially regulatory genes. It appeared that vector pHX200 is an efficient promoter probe with wide host-range and an excellent tool for studies of structure and function of promoters/regulators.
\end{abstract}

\section{Introduction}

Methylotrophic bacteria use one-carbon compounds more reduced than carbon dioxide as carbon and energy source. Carbon assimilation occurs at the oxidation level of formaldehyde (Anthony, 1982). Methylobacterium organophilum XX is a pink-pigmented facultative methylotrophic bacterium that utilizes methanol, methylamine, sugars, fatty acids and complex nutrients for growth (Patt et al., 1976). It is a type II methylotroph that utilizes the serine pathway for formaldehyde assimilation. Type I methylotrophs utilize the hexulose monophosphate pathway for the same purpose (Anthony, 1982). The enzymes involved in growth of some facultative methylotrophs on one-carbon compounds

*Author for correspondence. Tel. (612) 4717741 ; fax (612) 4719070.

Abbreviations: $\mathrm{MDH}$, methanol dehydrogenase; $\mathrm{PQQ}$, pyrroloquinoline quinone; S-D, Shine-Dalgarno. can be induced by methanol or methylamine (Anthony, 1982; O'Connor \& Hanson, 1977). The oxidation of methanol to formaldehyde is catalysed by methanol dehydrogenase (MDH). It is a periplasmic enzyme and contains the prosthetic group pyrroloquinoline quinone (PQQ). This enzyme has been found in all Gramnegative methylotrophic bacteria examined. The MDH enzymes are tetramers of two types of subunits in an $\alpha_{2} \beta_{2}$ conformation (Anthony, 1986; Cox et al., 1992; Nunn et al., 1989). The large subunit ( $\alpha$ subunit) has a molecular mass of 56 to $76 \mathrm{kDa}$, while the small subunit $(\beta$ subunit) has a molecular mass of 8 to $10 \mathrm{kDa}$ (Anthony, 1982, 1986; Cox et al., 1992; Nunn et al., 1989). The MDH large subunit structural gene $(\operatorname{mox} F)$ and its upstream region (492 bp) from $M$. organophilum XX have been cloned and sequenced, and its transcriptional start site and promoter have been identified (Machlin \& Hanson, 1988). Genetic studies of MDH synthesis in $M$. organophilum XX indicated (Allen \& Hanson, 1985; Machlin et al., 1987, 1988; Bastien et al., 1989) that at 
least seven separate chromosomal regions (groups I to VII) encode at least 15 genes that are required for methanol oxidation and formaldehyde assimilation, and that a total of five genes, including the MDH structural genes moxF and moxI, map within group V.

Despite identification of gene clusters required for methanol oxidation, the mechanisms of regulation of $\operatorname{mox} F$ and other related genes in methylotrophic bacteria remain unclear. To study the structure and function of methanol-regulated promoters, the availability of a promoter-probe vector applicable in methylotrophs is essential. Previous attempts to use pho $A$ and lac $Z$ as reporter genes in $M$. organophilum XX have been unsuccessful (R. S. Hanson, unpublished data). Recently, the catechol 2,3-dioxygenase gene $(x y l E)$ from Pseudomonas putida has been used successfully as the reporter gen in a number of phylogenetically diverse micro-organisms in which other reporter genes were poorly expressed (Zukowski et al., 1983; Ingram et al., 1989; Ray et al., 1985, 1988; Winstanley et al., 1989; Hahn et al., 1991). Therefore, the $x y l E$ gene was selected as a candidate for a reporter gene for constructing a promoter-probe vector mobilizable into $M$. organophilum XX and other methylotrophs.

This study was undertaken to construct a promoterprobe vector and use it to identify methanol-regulated promoter sequences from $M$. organophilum XX. Moreover, expression of transcriptional fusion constructs was examined in $\mathrm{Mox}^{-}$mutants of both $M$. organophilum XX and Methylobacterium extorquens AM1.

\section{Methods}

Bacterial strains, plasmids, and growth conditions. The bacterial strains and plasmids used in this study are listed in Table 1. Escherichia coli strains were grown in LB medium at $37^{\circ} \mathrm{C}$. Methylophilus methylotrophus AS1 was grown in CJ medium (Windass et al., 1980) plus methanol at $37^{\circ} \mathrm{C}$. Methylobacterium organophilum XX, Methylobacterium extorquens AM1 and Methylobacterium sp. DM4 were grown in MacLennan minimal medium (MM) (MacLennan et al., $1971)$ containing $0.5 \%(\mathrm{v} / \mathrm{v})$ methanol or $0.1 \%(\mathrm{w} / \mathrm{v})$ succinate at $30{ }^{\circ} \mathrm{C}$. When required, antibiotics were added to final concentrations of $50 \mu \mathrm{g} \mathrm{ml}^{-1}$ of ampicillin (Ap) and kanamycin (Km) for E. coli strains; $15 \mu \mathrm{g} \mathrm{ml}^{-1}$ and $20 \mu \mathrm{g} \mathrm{ml}^{-1}$ of tetracycline (Tc) for $E$. coli and $M$. organophilum XX, respectively; $1.5 \mu \mathrm{g} \mathrm{ml}^{-1}$ of Tc for Methylophilus methylotrophus AS1; and $4 \mu \mathrm{g} \mathrm{ml}^{-1}$ of $\mathrm{Tc}$ for Methylobacterium extorquens AM1 and Methylobacterium sp. DM4.

DNA manipulation. Plasmid isolation and purification, restriction endonuclease digestion, ligation, DNA dephosphorylation and Southern blotting and hybridization were performed as described in Sambrook et al. (1989). E. coli JM109 competent cells were transformed with various plasmid constructs based on the protocols provided by Promega Corp.

$P C R$ amplification of the xylE gene. Oligonucleotide primers (XYLE primer1 5'-CAAGATCTGAATTCAGGAGGTGACGTCATG-3'; XYLE primer2 5'-CCCTGCAGGACCATCAGGTC-3') were designed based on the $x y l E$ nucleotide sequence (Zukowski et al., 1983) and synthesized by American Synthesis Inc. A modified promoterless $x y l E$ gene was synthesized by PCR based on the protocol of Perkin Elmer/Cetus Co.

Bacterial matings. Donor E. coli cells (containing mobilizable plasmids) were mated with Methylobacterium organophilum XX (wildtype or mutants), M. extorquens AM1, Methylobacterium sp. DM4 and Methylophilus methylotrophus AS1 for mobilization of plasmids as described previously (Allen \& Hanson, 1985), with modifications. Matings involving Methylophilus methylotrophus AS1 as recipient were performed on a mixed medium of $\mathrm{CJ}$ and Antibiotic medium 3 (Difco) (ratio $=1 / 1$ ). The others were performed on Antibiotic medium 3 . Selection of transconjugants was achieved by replica plating onto MMmethanol plates (wild-type) or MM-methanol-succinate plates (mutants) with appropriate concentrations of tetracycline. CJ minimal medium replaced MM when Methylophilus methylotrophus AS1 transconjugants were selected. Plates were incubated for 3 to $5 \mathrm{~d}$ at $30^{\circ} \mathrm{C}$ for most species except Methylophilus methylotrophus AS1, which was grown at $37^{\circ} \mathrm{C}$. Colonies of transconjugants were streaked on fresh plates of the same medium for purification.

Catechol 2,3-dioxygenase activity. Assays for the enzyme were performed as described by Zukowski et al. (1983) and Kataeva \& Golovleva (1990), with slight modifications. Functional expression of the $x y l E$ gene was examined by spraying filters (Whatman filter paper no. 3) onto which colonies were replicated with a fresh aqueous solution of $0 \cdot 1 \mathrm{M}$-catechol. Catechol 2,3-dioxygenase transformed catechol into a yellow product, 2-hydroxymuconic semialdehyde. Colonies of cells that expressed $x y l E$ became yellow or produced the diffusible yellow product. For quantitative assays, the enzyme reaction was conducted in a cuvette (light-path $1 \mathrm{~cm}$ ) in a total volume of $1 \mathrm{ml}$ containing: $0.8 \mathrm{ml} 50 \mathrm{~mm}$-Tris buffer ( $\mathrm{pH} \mathrm{7.5);0.1} \mathrm{ml} 10$ mM-catechol dissolved in the Tris buffer; $0.1 \mathrm{ml}$ cell-free protein extract or dilutions. Cell-free extracts were prepared as described by Machlin et al. (1987). The rate of reduction was taken as two times the change in absorbance at $375 \mathrm{~nm}$ between 15 and $45 \mathrm{~s}$ after mixing the components of the reaction. One milliunit corresponds to the formation of $1 \mathrm{nmol} \mathrm{2-}$ hydroxymuconic semialdehyde per min at $30^{\circ} \mathrm{C}$. Protein concentrations were measured by the method of Bradford (1976), using bovine serum albumin as standard.

Primer extension. Total RNA was isolated from $M$. organophilum XX by the method of Zhu \& Kaplan (1985). Hybridization of purified RNA $(20 \mu \mathrm{g})$ with $4 \times 10^{5}$ c.p.m. of radiolabelled oligonucleotide primer and primer extension were performed as described by Kingston (1989).

Identification of methanol-regulated promoters. Cosmids pS1033, pS150 and pS23 with inserts of $M$. organophilum XX chromosomal DNA including group V, VI and VII complementation clusters involved in methanol oxidation (Machlin et al., 1987) were partially digested with Sau3A and ligated into the BamHI site of pHX200. E. coli JM109 competent cells were transformed by the ligation mixture and tetracycline-resistant transformants were mated, by replica plating, with wild-type $\boldsymbol{M}$. organophilum XX cells. Transconjugants grown on MM-methanol-Tc plates were sprayed with catechol to identify clones in which inserts promoted the expression of $x y l E$. In order to exclude promoter sequences derived from the pLA2917 vector, each recombinant plasmid was digested with Pst I and fractionated on $0.9 \%$ agarose gel. Southern blots were prepared and hybridized with the radiolabelled plasmid vector pLA2917 based on protocols of Schleicher \& Schuell, Inc. Those inserts that hybridized to the vector were excluded from further studies. Insert sizes were estimated after agarose gel electrophoresis.

Sequencing of promoter inserts. Two oligonucleotide primers were designed for sequencing of promoter inserts from both upstream and 
Table 1. Bacterial strains and plasmids

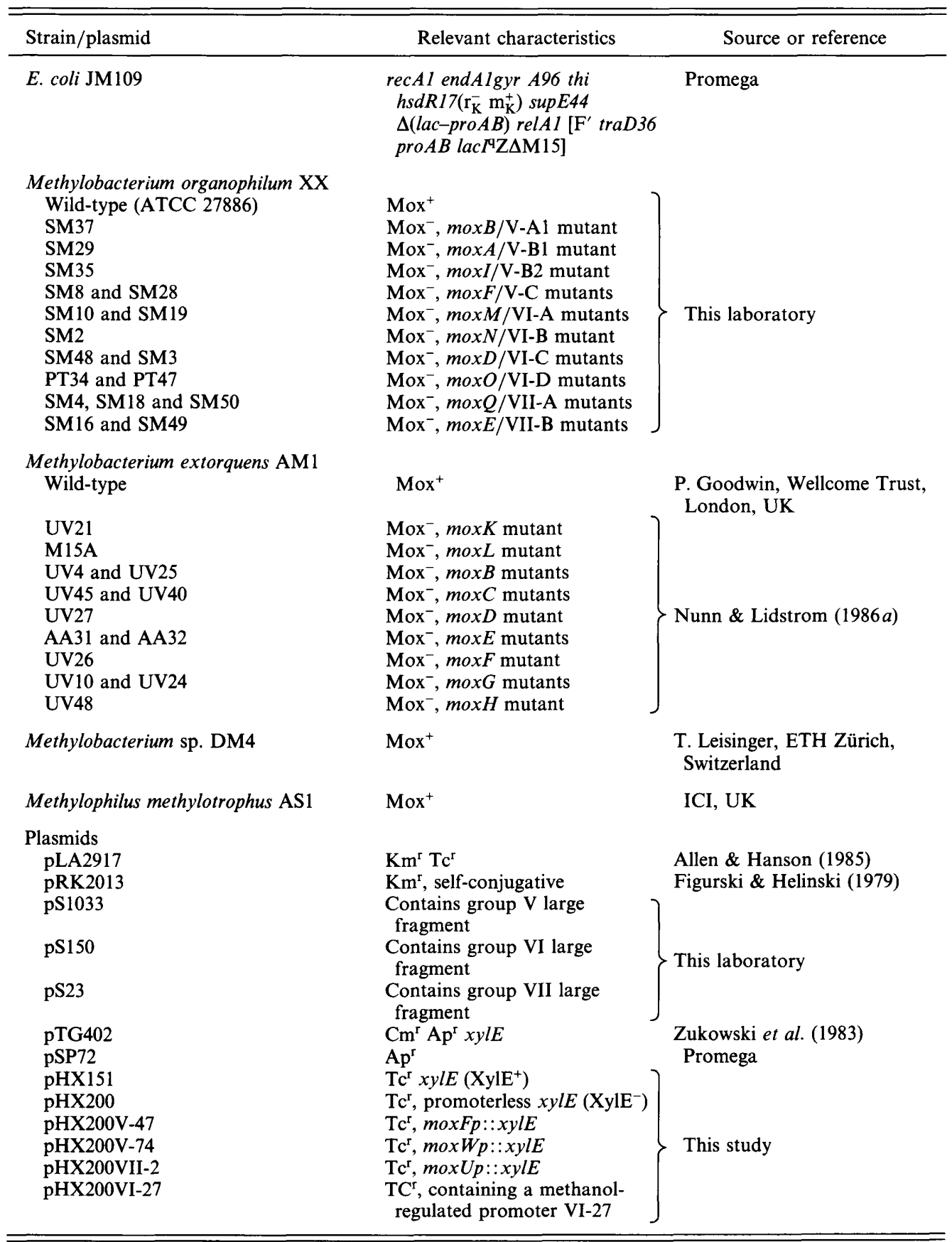

downstream halves of the interrupted polylinker. The sequence of the upstream primer is $5^{\prime}$-TGCCTGCAGGTCGAC- $3^{\prime}$ and the sequence of the downstream primer is $5^{\prime}$-AGATCTGATATCATC-3'. Doublestranded plasmid DNAs were directly used for sequencing based on protocols provided with the Sequenase Version 2.0 Sequencing Kit by US Biochemical.

Nucleotide sequence access number. The nucleotide sequence ( $500 \mathrm{bp}$ ) of the mox $F$ upstream region was determined by Machlin \& Hanson (1988) and has been deposited in GenBank (accession number LO 7547).

\section{Results}

Construction of promoter-probe vector

A promoterless $x y l E$ gene was synthesized by PCR amplification from plasmid pTG402. The original $x y l E$ gene was expressed in Methylobacterium organophilum $\mathrm{XX}$ but not at a high enough level to be used as a reporter gene in the pink-coloured cells $(\mathrm{H} . \mathrm{H} . \mathrm{Xu}$, 
(a)

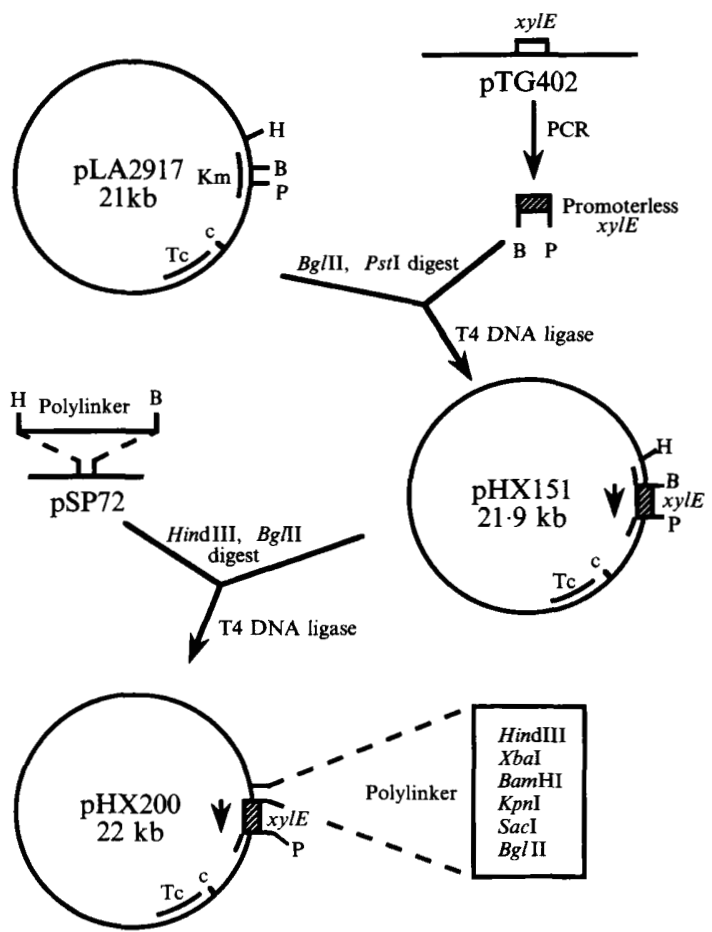

(b)

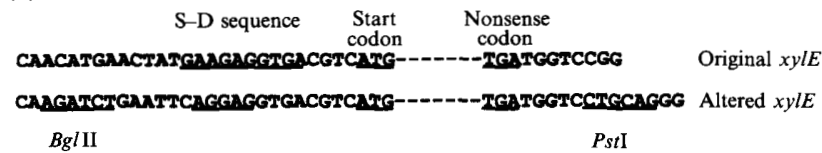

Fig. 1. Construction of promoter-probe vector pHX200. (a) DNA manipulation scheme; (b) S-D sequence comparison of the original and modified $x y l E$ genes. Abbreviations: P, PstI ; B, BglII ; H, HindIII; c, cos site; $\mathrm{Km}$, kanamycin; $\mathrm{Tc}$, tetracycline; ---, $\operatorname{mox} F$ open reading frame.

unpublished data). The most probable reason for poor expression was low efficiency of ribosomal binding on the $x y l E$ mRNA in $M$. organophilum XX cells. Therefore, the S-D (Shine-Dalgarno) sequence of the $x y l E$ gene was modified during PCR amplification of the gene to resemble the S-D sequence of the mox $F$ gene (Fig. $1 b$ ). As shown in Fig. 1(a), plasmid pLA2917 was digested with $B g I I I$ and PstI, sites for which reside within the kanamycin-resistance gene. The large fragment was ligated with the $B g l \mathrm{II}-$ and PstI-digested promoterless $x y l E$ gene fragment, producing construct $\mathrm{pHX} 151$ with a defective kanamycin-resistance gene. Plasmid pHX151, when mobilized into $M$. organophilum XX, expressed $x y l E$ efficiently due to the intact kanamycin promoter. The HindIII-BglII fragment on $\mathrm{pHX} 151$ containing the kanamycin promoter was replaced by the polylinker fragment from pSP72, producing the vector $\mathrm{pHX} 200$ whose $x y l E$ was not expressed in $M$. organophilum XX

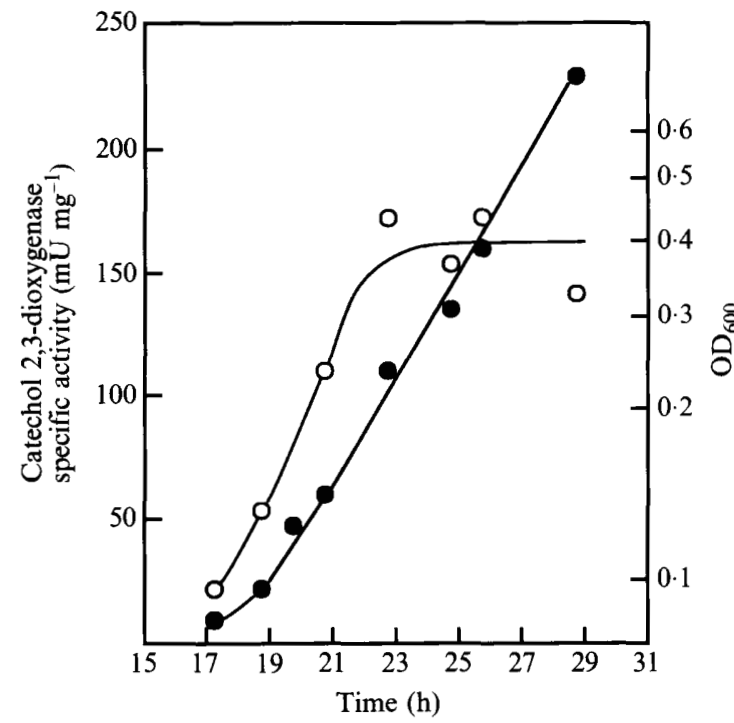

Fig. 2. mox $F$ promoter activity during growth of $M$. organophilum XX. $M$. organophilum XX cells were grown in methanol minimal medium plus tetracycline. The bacterium contained plasmid construct pHX200V-47, in which $x y l E$ is under control of the moxF promoter. The mox $F$ promoter activity was indicated by $x y l E$ reporter gene expression. $\bigcirc$, Catechol 2,3-dioxygenase specific activity; $\mathbf{O}$, bacterial growth. Experiments were replicated at least twice; each data point is the mean of three replicate assays from a single experiment.

unless an active promoter was inserted within the polylinker. The polylinker contains the following unique restriction sites: HindIII, $X b a \mathrm{I}, B a m \mathrm{HI}, K p n \mathrm{I}, S a c \mathrm{I}$ and BglII.

\section{Cloning of moxF promoter in front of $x y l E$}

A 448 bp KpnI fragment containing the promoter region of the moxF gene was excised and inserted into the $K p n \mathrm{I}$ site of the vector $\mathrm{pHX} 200$. The recombinant plasmids were mobilized into $M$. organophilum XX cells. Six transconjugant clones of $M$. organophilum XX produced a yellow colour after spraying with catechol solution. One of the clones was selected for sequence confirmation. The recombinant plasmid (designated pHX200V-47) was isolated from the corresponding $E$. coli JM109 strain and was sequenced using Sequenase Version 2.0. This plasmid contained an insert with a sequence identical to that of the mox $F$ upstream promoter region. This fragment was inserted in front of $x y l E$ in the same orientation as that of the $\operatorname{mox} F$ promoter sequence.

The $M$. organophilum XX clone containing recombinant plasmid pHX200V-47 was grown in liquid MM-methanol-Tc medium at $30^{\circ} \mathrm{C}$, and cell growth and $x y l E$ activity were monitored (Fig. 2). The specific activity of catechol 2,3-dioxygenase (the $x y l E$ gene product) increased at a similar rate as cell density from lag phase to $\operatorname{OD}_{600} 0 \cdot 25$ and then remained relatively 


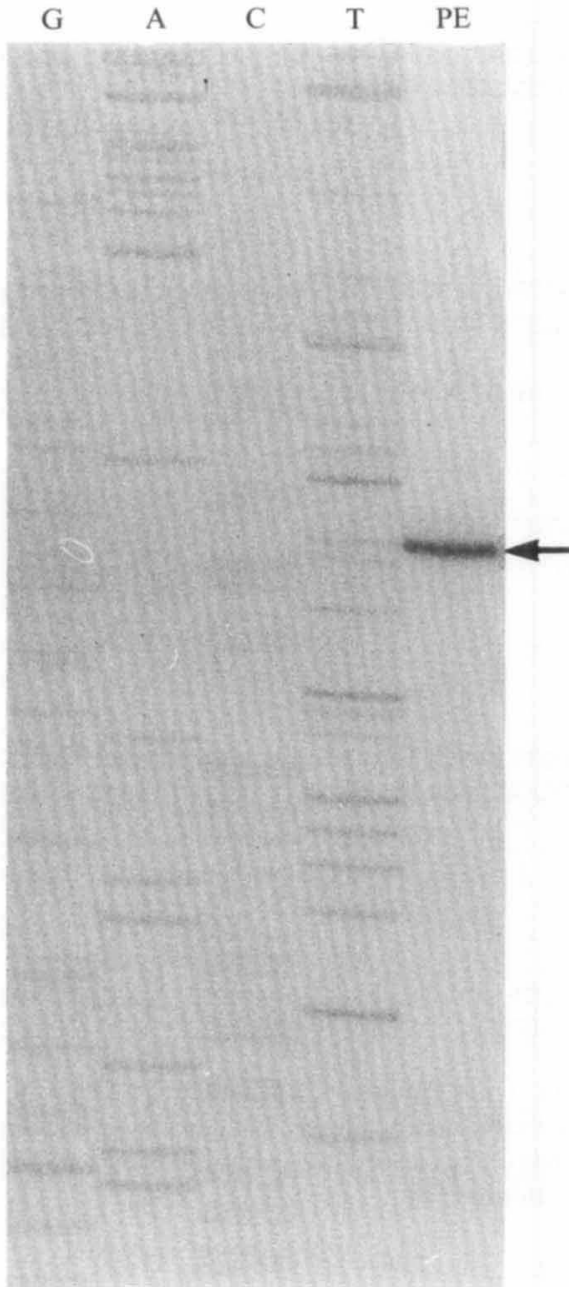

Fig. 3. Identification of the transcription start site of $\operatorname{mox} W$. Autoradiography of primer extension experiment. G, A, C and T represent lanes loaded with standard sequencing reactions; $P E$ marks the lane loaded with primer extension. The arrow points to the DNA band that was extended from the primer.

constant between $\mathrm{OD}_{600}$ values of 0.2 and 0.7 . Therefore, the assays for catechol 2,3-dioxygenase activity were performed using cell-free extracts obtained from cultures at $\mathrm{OD}_{600} 0 \cdot 5$.

\section{Discovery of an upstream divergently transcribed gene}

Computer analysis of the upstream nucleotide sequence of $\operatorname{mox} F$ revealed one open reading frame that may be transcribed divergently from the mox $F$ gene. This gave rise to the hypothesis that a divergently transcribed gene upstream of $\operatorname{mox} F$ exists which might be inducible by methanol and involved in methanol oxidation. If this were the case, we should be able to find a clone among the above six transconjugants which contains a plasmid with the $448 \mathrm{KpnI}$ fragment inserted in the opposite orientation to that in pHX200V-47. To test this hypothesis, five additional positive promoter plasmids identified above that promoted $x y l E$ expression in $M$. organophilum $\mathrm{XX}$ were sequenced. Three of them contained $448 \mathrm{bp}$ inserts with the same insertion orientation as that in pHX200V-47 (see above); two others contained the same inserts in the opposite orientation (designated pHX200V-74). This indicated that the putative upstream divergently transcribed gene has an active promoter. This promoter also was shown to be regulated by methanol (see below). This upstream divergently transcribed gene is named $\operatorname{mox} W$.

\section{Transcriptional start site of the moxW gene}

The $M$. organophilum XX clone containing pHX200V-74 was grown in MM-methanol-Tc medium to allow transcription of the $x y l E$ gene controlled by the moxW promoter. The oligonucleotide primer used in primer extension reactions was the same as the downstream primer used for sequencing. Primer extension experiments (Fig. 3) identified the site of transcriptional start for the mox $W$ gene $(\mathrm{W}+1)$ to be $143 \mathrm{bp}$ upstream of the mox $F$ transcriptional start site (Fig. 4).

\section{Identification of methanol-regulated promoter clones}

To further test the ability of the vector to 'capture' unknown promoter sequences from $M$. organophilum XX DNA and also provide material for future studies of promoters and regulators in this organism, three large DNA fragments (25 to $30 \mathrm{~kb})$ containing three gene clusters involved in methanol oxidation were used to identify methanol-regulated promoter sequences. Cosmids containing the fragments were digested with Sau3A and ligated with BamHI-cleaved pHX200. E. coli JM109 competent cells were transformed with the ligation mixture. Transformants were mated with wild-type $M$. organophilum XX cells. Transconjugants were screened for positive promoter clones in which inserted fragments promoted expression of the $x y l E$ gene. Thirty-two positive promoter clones were identified. After further screening, only 19 clones were determined to be methanol-regulated promoters. The other 13 were excluded either because the promoter sequences were derived from the cosmid vector or because they were also strongly expressed in succinate minimal medium. Qualitative results showed that $M$. organophilum XX clones containing these 19 plasmids produced a high level of catechol 2,3-dioxygenase when they were grown on a medium containing methanol, while they exhibited much lower or no catechol 2,3-dioxygenase activity when they were grown on succinate. Besides the promoters of $\operatorname{mox} F$ and moxW (whose sequence has been published), six of 
1 CCCGGGGAAGCGGGCGCGGTCGCTGCCGGTGAGGTCGCGCCGGCCGTCGCGGGGATAGAGGGCGCCGGTCTCGCCGACGTCCCGCGCGCCCGGCCAGACG GGGCCCCTTCGCCCGCGCCAGCGACGGCCACTCCAGCGCGGCCGGCAGCGCCCCTATCTCCCGCGGCCAGAGCGGCTGCAGGGCGCGCGGGCCGGTCTGC

101

CGAGCGCCAACCCCGCCGCCAGGCCATGCCAGCCTCGCGCCATCACTGCTCCTCCCGATGTCTCGGGCCGCTGCCGCCCGTTCCGCCT AGTGGTGCGCCG GCTCGCGGTTGGGGCGGCGGTCCGGTACGGTCGGAGCGCGGTAGTGACGAGGAGGGCTACAGAGCCCGGCGACGGCGGGCAAGGCGGATCACCACGCGGC

$$
\text { mOXN ORF }
$$

moxw transcription start

-10 w

$(\mathfrak{w}+1)$

201

GGCCTTCGTCGCGGTCAAGCCGGAGGGATACGAGAAGATCGCCAATTTAGAMTGCCACATCTTCCCAGCAAGAAATGTCTGACCGGGTAMAACATCTC CCGGAAGCAGCGCCAGTICGGCCTCCCTATGCTCTTCTAGCGGTTAAATCTTTACGGTGTAGAAGGGTCGTTCTTTACAGACTGGCCCATTTCTGTAGAG $-35 w$ $\gg \gg \gg$ $\ll<<$

\author{
$(\mathrm{F}+1)$ \\ moxF transcription start \\ $301 \quad-10 F \quad 1----->$ \\ CTTCAATCAACGCCTAGAAACATAGGCGACGGGTGCTAATAAGTCTTTCATAAGACAGAGTTTATCTAAGATTGTTCTTAGATTTTCTGCTCGGTCGAG \\ GAAGTTAGTTGCGGATCTTTGCTATCCGCTGCCCACGATTAT'TCAGAAAGTATTCTGTCTCAAATAGATTCTAACAAGAATCTAAAAGACGAGCCAGCTC
}

GAATGGACTTCGTGGCGAACCCTGAACCTCAGAGGGATAGCTCAAGAGGTACCGCGAGGCCGAAAGGCGTGGCGGTCAAGCGAGGAGACGCAGGATGAG CTTACCTGAAGCACCGCTTGGGACTTGGAGTCTCCCTTATCGAGTTCTCCATGGCGCTCCGGCTTTCCGCACCGCCAGTTCGCTCCTCTGCGTCCTACTC

Fig. 4. Transcriptional start site of mox $W$ and its surrounding nucleotide sequence. Transcriptional start sites (designated as $\mathrm{W}+1$ and $\mathrm{F}+1$, respectively) and transcription direction of the mox $W$ and $\operatorname{mox} F$ genes are indicated by arrows. Open reading frames are also indicated by arrows. Shine-Dalgarno (S-D) sequences, and -10 and -35 hexamers of the mox $W$ and mox $F$ promoters, are underlined. Repeated septanucleotides are indicated by bold letters. The dyad symmetry is indicated by $>>>><<<<$.

19 promoter fragments were sequenced $(\mathrm{H} . \mathrm{H} . \mathrm{Xu}$ and others, unpublished data) and they represent six different sequences. For the rest of the promoter fragments, it is possible that some are duplicates within each group (e.g. group V, VI or VII).

\section{Induction of promoter activity by methanol}

Four promoter clones were examined for quantitative expression of the $x y l E$ gene (i.e. promoter activity) in the presence and absence of methanol. Clones of $M$. organophilum XX containing $\mathrm{pHX} 200 \mathrm{~V}-47$, pHX200V74, pHX200VI-27 or pHX200VII-2 were grown in liquid MM-methanol-Tc and MM-succinate-Tc media. Cells were harvested at $\mathrm{OD}_{600} \mathbf{0 . 5}$ and cell-free extracts were made. The catechol 2,3-dioxygenase activity of each clone was measured under each growth condition (Fig. 5 ). The results indicate that under control of these four promoters, the $x y l E$ gene was expressed at higher levels in methanol-grown cells than in succinate-grown cells. The mox $F$ promoter in the pHX200V-47 construct produced the highest level of methanol-induced $x y l E$ expression. This was not surprising since MDH $(\operatorname{mox} F$ encodes the large subunit of $\mathrm{MDH}$ ) comprised $15 \%$ of the total protein of $M$. organophilum XX during growth on methanol (P. E. Tam \& R. S. Hanson, unpublished data). The $\operatorname{mox} F$ promoter gave a lower but significant amount of $x y l E$ gene expression during growth on succinate. This is consistent with previous results which have shown that methanol dehydrogenase is synthesized at a relatively high background level, indicating loose regulatory control (O'Connor \& Hanson, 1977). In contrast, $x y l E$ expression controlled by the promoter of mox $W$ in the pHX200V-74 construct was shown to be under strict regulation. The $x y l E$ specific activity was $23 \mathrm{mU} \mathrm{mg}^{-1}$ in presence of methanol but was zero (or below detection level) in absence of methanol.

\section{Host range of vector $p H X 151, p H X 200$ and $p H X 200 \mathrm{~V}$ - 47}

Vector $\mathrm{pHX} 200$, its parent $\mathrm{pHX} 151$ and one promotercontaining derivative ( $\mathrm{pHX} 200 \mathrm{~V}-47)$ were mobilized into three other phylogenetically diverse methylotrophic bacteria (Methylobacterium extorquens AM1, Methylobacterium sp. DM4 and Methylophilus methylotrophus 


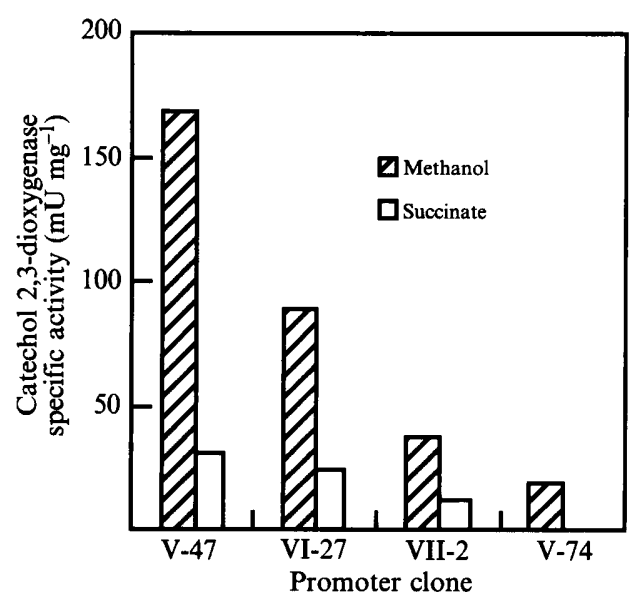

Fig. 5. Comparison of promoter activities under different growth conditions. $M$. organophilum XX clones containing one of the four plasmids (pHX200V-47, pHX200VI-27, pHX200VII-2 and pHX200V74) carrying various promoter clones were grown in either methanol or succinate minimal media. Experiments were replicated at least twice; each data point is the mean of three replicate assays from a single experiment.

AS1) (Tsuji et al., 1990). The results showed that all four clones of methylotrophic bacteria containing pHX151 (in which the kanamycin promoter controls $x y l E$ expression) became yellow-coloured after spraying with a catechol solution. This indicates that $x y l E$ (at least the modified $x y l E)$ is an efficient reporter gene in these bacterial systems. Introduction of $\mathrm{pHX} 200$ vector did not lead to expression of $x y l E$ in three of the four methylotrophs ( $M$. organophilum XX, M. extorquens AM1 and Methylobacterium sp DM4). This indicates that the vector is useful as promoter probe vector in these three bacterial systems. This observation was confirmed by the high-level expression of $x y l E$ by these cells once a methanol-regulated promoter (the mox $F$ promoter) was inserted into pHX200. The vector cannot be used in Methylophilus methylotrophus AS1 without further modifications, because $x y l E$ of $\mathrm{pHX} 200$ was expressed in this bacterium.

Two classes of $M_{0 x}^{-}$mutants of $M$. organophilum $X X$ and $M$. extorquens $A M I$

For convenience of discussion, the putative gene controlled by a newly identified methanol regulated promoter VII-2 (carried by plasmid pHX200VII-2) is tentatively named moxU. Transcription fusion plasmids pHX200V-47 (moxFp::xylE), pHX200V-74 (moxWp $:: x y l E$ ) and pHX200VII-2 (moxUp::xylE) were individually mobilized into each of $17 \mathrm{Mox}^{-}$mutants of $M$. organophilum XX. These 17 mutants represent 10 loci involved in methanol oxidation. Results with $\mathrm{pHX} 200 \mathrm{~V}$ 47 showed that, as expected, mutations in the structural
Table 2. Expression of the xylE gene fused to different promoter regions in Mox mutants of $M$. organophilum $X X$

\begin{tabular}{|c|c|c|c|c|}
\hline \multirow[b]{2}{*}{ Mutant } & \multirow[b]{2}{*}{ Locus } & \multicolumn{3}{|c|}{ Transcriptional fusion } \\
\hline & & $\operatorname{mox} F p:: x y l E$ & $\operatorname{mox} W p:: x y l E$ & $\operatorname{mox} U p:: x y l E$ \\
\hline SM37 & $\operatorname{mox} B$ & - & + & + \\
\hline SM4 & $\operatorname{mox} Q$ & - & + & + \\
\hline SM18 & $\operatorname{mox} Q$ & - & + & + \\
\hline SM50 & $\operatorname{mox} Q$ & - & + & + \\
\hline SM16 & $\operatorname{mox} \bar{E}$ & - & + & + \\
\hline SM49 & $\operatorname{mox} E$ & - & + & + \\
\hline SM10 & $\operatorname{mox} M$ & - & - & - \\
\hline SM19 & $\operatorname{mox} M$ & - & - & - \\
\hline SM2 & $\operatorname{mox} N$ & - & - & - \\
\hline SM48 & $\operatorname{mox} D$ & - & - & - \\
\hline SM3 & $\operatorname{mox} D$ & - & - & - \\
\hline SM29 & $\operatorname{mox} A$ & + & + & - \\
\hline SM35 & $\operatorname{mox} I$ & + & + & - \\
\hline SM8 & $\operatorname{mox} F$ & + & + & - \\
\hline SM28 & $\operatorname{mox} F$ & + & + & - \\
\hline PT34 & $\operatorname{mox} O$ & + & + & - \\
\hline PT47 & $\operatorname{mox} O$ & + & + & - \\
\hline
\end{tabular}

Table 3. Expression of the xylE gene fused to different promoters in Mox - mutants of M. extorquens AM1

\begin{tabular}{llcc}
\hline \hline & & \multicolumn{2}{c}{ Transcriptional fusion } \\
\cline { 3 - 4 } Mutant & Locus & moxFp::xylE & $\operatorname{mox} W p:: x y l E$ \\
\hline UV4 & $\operatorname{mox} B$ & - & + \\
UV25 & $\operatorname{moxB}$ & - & + \\
AA31 & $\operatorname{mox} E$ & - & + \\
AA32 & $\operatorname{mox} E$ & - & + \\
UV27 & $\operatorname{moxD}$ & - & - \\
UV21 & $\operatorname{mox} K$ & + & + \\
M15A & $\operatorname{mox} L$ & + & + \\
UV40 & $\operatorname{mox} C$ & + & + \\
UV45 & $\operatorname{moxC}$ & + & + \\
UV26 & $\operatorname{moxF}$ & + & + \\
UV10 & $\operatorname{moxG}$ & + & + \\
UV24 & $\operatorname{moxG}$ & + & + \\
UV48 & $\operatorname{moxH}$ & + & + \\
\hline \hline
\end{tabular}

genes of MDH large subunit (mox $F$ ) and small subunit (moxI) did not affect the expression of the $x y l E$ gene (Table 2). On the other hand, mutations in the $\operatorname{mox} Q$ and moxE genes previously implicated as regulatory genes (Nunn \& Lidstrom, 1986b; Lidstrom, 1990) were confirmed by this assay to be involved in regulation of $\operatorname{mox} F$ transcription. Mutations on loci mox $A$ and moxO did not affect mox $F$ expression. But the opposite results were observed in mutants defective in loci $\operatorname{mox} B, \operatorname{mox} M$, $\operatorname{mox} N$ and $\operatorname{mox} D$. In comparison, $\operatorname{mox} W$ promoter activity was affected only by mutations in the mox $M$, $\operatorname{mox} N$ and moxD genes (Table 2). Furthermore, the activity of the mox $U$ promoter carried by pHX200VII- 2 
was inhibited by most mutations except those in the $\operatorname{mox} B, \operatorname{mox} Q$ and $\operatorname{mox} E$ genes (Table 2).

Transcriptional fusion plasmids pHX200V-47 (mox$F p:: x y l E)$ and pHX200V-74 (moxWp::xylE) were mobilized into $13 \mathrm{Mox}^{-}$mutants of $M$. extorquens AM1. Mutations in $\operatorname{mox} K, \operatorname{mox} L, \operatorname{mox} C, \operatorname{mox} F, \operatorname{mox} G$ and $\operatorname{mox} H$ did not influence the activity of either the mox $F$ promoter or the mox $W$ promoter (Table 3). Mutations in two regulatory loci (moxB and moxE) abolished activity of the $\operatorname{mox} F$ promoter but not activity of the moxW promoter (Table 3). Homogenous loci from $M$. extorquens $\mathrm{AM} 1$ and from $M$. organophilum XX had identical effects on both moxFp:: xylE and mox $W p:: x y l E$ fusions (Tables 2 and 3 ).

\section{Discussion}

A number of vectors employing $x y l E$ as the reporter gene have been developed in systems where well-established reporter genes such as $\operatorname{lac} Z$ were not very effective (Zukowski et al., 1983; King \& Chater, 1986; Ray et al., 1988, 1985; Winstanley et al., 1989). In contrast, very little has been reported on the application of reporter genes in methylotrophs. Attempts to use lac $Z$ and phoA as reporter genes in $M$. organophilum XX were unsuccessful (R. S. Hanson, unpublished data). Recently, Morris \& Lidstrom (1992) utilized the lac $Z$ gene as the reporter gene and studied the promoter activity of the moxF upstream region from Methylobacterium extorquens AM1rif. They constructed a transcriptional fusion between the lac $Z$ gene and a $1.55 \mathrm{~kb}$ fragment containing the $5^{\prime}$ portion of the mox $F$ gene and its 1289 bp upstream DNA. In our study, we cloned a 448 bp DNA fragment upstream of moxF (not including any mox $F$ structural sequence) in front of $x y l E$ gene and demonstrated that this $448 \mathrm{bp}$ fragment contained necessary elements for methanol-inducible regulation when carried by a plasmid. Interestingly, the transcriptional fusion described by Morris \& Lidstrom (1992) was not regulated by methanol when carried on the vector. The fusion was normally regulated by methanol once it was integrated into the chromosome (Morris \& Lidstrom, 1992).

In the present study, we have described the construction of a promoter-probe vector which uses $x y l E$ as the reporter gene. The vector was successfully employed to detect methanol-regulated DNA fragments from $M$. organophilum XX that promote the expression of $x y l E$ in vivo. In particular, this vector enabled us to identify a divergently transcribed gene (mox $W$ ) upstream of $\operatorname{mox} F$. The moxW gene was also shown to be regulated by methanol. This is significant because it demonstrated that vector $\mathrm{pHX} 200$ is a very efficient promoter-probe vector. Besides identification of methanol-regulated promoters, vector $\mathrm{pHX} 200$ can also be used to identify other types of promoter fragments such as succinateregulated, or general 'housekeeping' promoters from methylotrophic bacteria by observing the expression of promoter clones under different growth conditions.

In both M. organophilum XX and M. extorquens AM1, methanol oxidation is not repressed by the presence of multi-carbon compounds (Anthony, 1982; O'Connor, 1981). Fifteen genes that are involved in methanol oxidation in $M$. organophilum XX have been identified (Allen \& Hanson, 1985; Machlin et al., 1987, 1988). Seventeen genes were found to be involved in methanol oxidation in $M$. extorquens AM1 (Nunn \& Lidstrom, $1986 a, b$; Lidstrom, 1990). Most genes have homologues in these two species and in Methylosinus sp. 81Z (Bastien et al., 1989). The functions of several of these genes are not known. Genes involved in methanol oxidation can be divided into two categories. One includes genes that are involved in regulation of mox $F$ transcription (they are called 'pre mox $F$-regulation genes'). The other category contains genes that are either structural genes for MDH and MDH-specific electron-carrier proteins or possess post-translational functions such as addition of the prosthetic group PQQ to the MDH apoprotein, transport of MDH to the periplasm, etc. (these are termed 'post mox $F$-regulation genes'). Mutations in these two types of genes can be differentiated by introducing plasmid pHX200V-47 (containing moxFp:: xylE fusion) into each $M$. organophilum XX mutant strain and measuring $x y l E$ expression after growing these mutants in a succinate minimal medium supplemented with methanol as an inducer. It should be pointed out that succinate does not decrease the specific activity of MDH when methanol is present in the growth medium (O'Connor, 1981). Mutants with mutations in genes of the post moxFregulation category are able to synthesize active $x y l E$ protein and produce a yellow colour after addition of catechol, because the $x y l E$ product does not require PQQ, cytochrome $c_{\mathrm{L}}$ or the small $\mathrm{MDH}$ subunit for activity, nor does it require a transport system for activity. In contrast, regulatory mutants of pre mox $F$ regulation genes where products are required for transcription of $\operatorname{mox} F$ cannot produce catechol 2,3-dioxygenase, because the $x y l E$ gene on the plasmid is controlled by the same mechanism as the chromosomal $\operatorname{mox} F$ gene and each regulatory mutation is defective in one of the steps prior to the activation of the $\operatorname{mox} F$ promoter. This assay therefore categorized $\operatorname{mox} B, \operatorname{mox} Q$, $\operatorname{mox} E, \operatorname{mox} M, \operatorname{mox} N$ and $\operatorname{mox} D$ as pre $\operatorname{mox} F$-regulation loci and $\operatorname{mox} A, \operatorname{mox} K, \operatorname{mox} L, \operatorname{moxI}, \operatorname{mox} F, \operatorname{mox} O$ and $\operatorname{mox} C$ as post $\operatorname{mox} F$-regulation genes.

It is logical to see that mutations which led to defective MDH large and small subunits did not interfere with the promoter activity of the $\operatorname{mox} F$ gene. The results of this study also confirmed the roles for the $\operatorname{mox} Q$ and $\operatorname{mox} E$ 
genes suggested previously (Machlin et al., 1987; Nunn $\&$ Lidstrom, 1986 b) and supported the proposed roles of $\operatorname{mox} A, \operatorname{mox} K$ and moxL (Lidstrom, 1990). Morris \& Lidstrom (1992) also introduced their transcriptional fusion into moxB mutants (UV4rif, UV25rif) to observe the effects of the mutation on the gene expression controlled by the $1.55 \mathrm{~kb}$ promoter fragment. In these mutants, lac $Z$ expression was reduced to the background level when the fusion was present in both plasmid and chromosomal locations. Their observation was consistent with our results that activity of $\operatorname{mox} F$ promoter was totally shut down by the mutations in locus $\operatorname{mox} B$ of mutants UV4, UV25 and SM37.

Inclusion of other methanol-regulated transcriptional fusions in this study enabled us to differentiate two types of regulatory genes. Mutations in the $\operatorname{mox} M, \operatorname{mox} N$ and moxD genes blocked expression of all three transcriptional fusions (moxFp::xylE, moxWp::xylE and moxUp::xylE). This suggests that these three methanol-regulated genes share the same induction mechanism. In contrast, mutations of the $\operatorname{mox} B, \operatorname{mox} Q$ and moxE genes only inhibited the moxFp::xylE fusion but not the other two, indicating that the mox $F$ gene has additional activation mechanisms that are governed by the $\operatorname{mox} B, \operatorname{mox} Q$ and $\operatorname{mox} E$ genes. These results showed that the transcriptional fusion system using $x y l E$ as reporter gene is a very efficient tool for categorizing methanol oxidation genes of $M$. organophilum XX and M. extorquens AM1.

In $M$. organophilum XX, both the mox $F$ and $\operatorname{mox} W$ promoters deviate significantly from the consensus sequence and have very poor recognition sites for RNA polymerase, suggesting positive regulation for both genes. These two promoters are both inducible by methanol. Their transcription start sites have been identified and are $143 \mathrm{bp}$ apart. In between these two start sites, there are three identical copies of a septanucleotide (AGAAATG), which has also been found in other newly identified methanol-regulated promoter sequences in relatively conserved form $(\mathrm{H} . \mathrm{H}$. Xu and others, unpublished data). Several copies of this septanucleotide are also present upstream of the mox $F$ gene from M. extorquens strain AM1 (Anderson et al., 1990). Deletional analysis indicated that removal of a nucleotide segment containing the distal (relative to mox $F$ transcription start) copy of the septanucleotide (see Fig. 4) totally abolished moxFp activity (H. H. Xu and others, unpublished data). There is a dyad symmetry (TGTCT$\mathrm{N}_{10}$-AGACA) overlapping with the -35 region of the mox $F$ promoter (see Fig. 4). This symmetry resembles a consensus sequence (TGTGT- $\mathrm{N}_{6-10}$-ACACA) of prokaryotic positive regulator binding sites (Gicquel-Sanzey \& Cossart, 1982). DNAase I footprinting experiments have indicated that this symmetry was protected against
DNAase I nicking after binding to the putative regulatory protein $(\mathrm{s})(\mathrm{H} . \mathrm{H} . \mathrm{Xu}$ and others, unpublished data).

We propose that $\operatorname{mox} M, \operatorname{mox} N$ and $\operatorname{mox} D$ are general positive regulatory genes for a group of methanolinducible genes (such as $\operatorname{mox} F$, moxW and $\operatorname{mox} U$ ). One of these regulatory genes may encode a DNA-binding protein capable of binding to the conserved septanucleotides in the upstream region of target genes. The $\operatorname{mox} F$ gene is also positively controlled by $\operatorname{mox} B, \operatorname{mox} Q$ and moxE genes, which have no influence on the expression of $\operatorname{mox} W$ and $\operatorname{mox} U$. One of these regulatory genes may encode a DNA-binding protein whose binding site is the dyad symmetry TGTCT-N 10 -AGACA.

This work was supported by a grant from the US Department of Energy (DOE-F602-88ER 13682). The $E$. coli strain containing pTG402 was kindly provided by Dr J.P. Lecocq of Transgene, Strasbourg, France. The mutants of Methylobacterium extorquens AM1 were gifts from D. Nunn and M. E. Lidstrom of California Institute of Technology, Pasadena, California, USA. We thank Dr Terese Barta for technical help and advice.

\section{References}

Allen, L. N. \& Hanson, R. S. (1985). Construction of broad-hostrange cosmid cloning vectors: identification of genes necessary for growth of Methylobacterium organophilum XX on methanol. Journal of Bacteriology 161, 955-962.

Anderson, D. J., Morris, C. J., NunN, D. N., Anthony, C. \& LidSTROM, M. E. (1990). Nucleotide sequence of the Methylobacterium extorquens AM1 moxF and moxJ genes involved in methanol oxidation. Gene 90, 173-176.

ANTHONY, C. (1982). The Biochemistry of Methylotrophs. New York: Academic Press.

ANTHONY, C. (1986). Bacterial oxidation of methane and methanol. Advances in Microbial Physiology 27, 113-210.

Bastien, C., Machlin, S., Zhang, Y., Donaldson, K. \& Hanson, R. S. (1989). Organization of genes required for the oxidation of methanol to formaldehyde in three Type II methylotrophs. Applied and Environmental Microbiology 55, 3124-3130.

BRADFORD, M. M. (1976). A rapid and sensitive method for the quantitation of microgram quantities of protein utilizing the principle of protein-dye binding. Analytical Biochemistry 72, 248-254.

Cox, J. M., DAY, D. J. \& ANTHONY, C. (1992). The interaction of methanol dehydrogenase and its electron acceptor, cytochrome $c_{\mathrm{L}}$, in methylotrophic bacteria. Biochimica et Biophysica Acta 1119, 97-106.

FiguRSKI, D. H. \& HelinsKI, D. R. (1979). Replication of an origincontaining derivative of plasmid RK2 dependent on a plasmid function provided in trans. Proceedings of the National Academy of Sciences of the United States of America 77, 7347-7357.

Gicquel-Sanzey, B. \& CossarT, P. (1982). Homologies between different procaryotic DNA binding regulatory proteins and between their sites of action. EMBO Journal 1, 591-595.

Hahn, D. R., SolenberG, P. J. \& Baltz, R. H. (1991). Tn5099, a xylE promoter probe transposon for Streptomyces spp. Journal of Bacteriology 173, 5573-5577.

Ingram, C., BraWner, M., Youngman, P. \& Westpheling, J. (1989). $x y l E$ functions as an efficient reporter gene in Streptomyces spp.: use for the study of galP1, a catabolic-controlled promoter. Journal of Bacteriology 171, 6617-6624.

Kataeva, I. A. \& Golovleva, L. A. (1990). Catechol 2,3-dioxygenases from Pseudomonas aeruginosa 2x. Methods in Enzymology 188, $115-121$.

KING, A. \& ChATER, K. F. (1986). The expression of the Escherichia coli lac Z gene in Streptomyces. Journal of General Microbiology 132, $1739-1752$. 
Kingston, R. E. (1989). Primer extension. In Current Protocols in Molecular Biology, pp. 4.8.1-4.8.3. Edited by F. M. Ausubel, R. Brent, R. E. Kingston, D. D. Moore, J. G. Seidman, J. A. \& Smith \& K. Struhl. New York: John Wiley.

LIDSTROM, M. E. (1990). Genetics of carbon metabolism in methylotrophic bacteria. FEMS Microbiology Reviews 87, 431-436.

MaChlin, S. M. \& Hanson, R. S. (1988). Nucleotide sequence and transcriptional start site of the Methylobacterium organophilum XX methanol dehydrogenase structural gene. Journal of Bacteriology 170, 4739-4747.

Machlin, S. M., Tam, P. E., Bastien, C. A. \& Hanson, R. S. (1987). Genetic and physical analysis of Methylobacterium organophilum XX genes encoding methanol oxidation. Journal of Bacteriology 170, 141-148.

Machlin, S. M., Tam, P. E., Allen, L. N. \& Hanson, R. S. (1988). Genetic studies of methanol metabolism in the facultative methylotroph, Methylobacterium organophilum XX. In Microbial Metabolism and the Carbon Cycle, pp. 381-392. Edited by S. R. Hagedorn, R. S. Hanson \& D. A. Kunz. New York: Harwood Academic Publishers.

Maclennan, D. G., Onsby, J. C., Vasey, R. B. \& Cotton, N. T. (1971). The influence of dissolved oxygen on Pseudomonas AM1 grown on methanol in continuous culture. Journal of General Microbiology 69, 395-404.

MorRIS, C. J. \& LiDstrom, M. E. (1992). Cloning of a methanolinducible $\operatorname{mox} F$ promoter and its analysis in $\operatorname{mox} B$ mutants of Methylobacterium extorquens AM 1rif. Journal of Bacteriology 174, $4444-4449$.

NunN, D. N. \& Lidstrom, M. E. (1986a). Isolation and complementation analysis of 10 methanol oxidation mutant classes and identification of the methanol dehydrogenase structure gene of Methylobacterium sp. strain AM1. Journal of Bacteriology 166, 581-590.

NunN, D. N. \& Lidstrom, M. E. (1986b). Phenotypic characterization of 10 methanol oxidation mutant classes in Methylobacterium sp. strain AM1. Journal of Bacteriology 166, 591-597.

NunN, D. N., DaY, D. \& ANThony, C. (1989). The second subunit of methanol dehydrogenase of Methylobacterium extorquens AM1. Biochemical Journal 260, 857-862.

O'CoNNOR, M. (1981). Regulation and genetics in facultative meth- ylotrophic bacteria. In Microbial growth on $C_{1}$ Compounds, pp. 294-300. Edited by H. Dalton. London: Heyden.

O'ConnoR, M. L. \& Hanson, R. S. (1977). Enzyme regulation in Methylobacterium organophilum. Journal of General Microbiology $\mathbf{9 8 ,}$ 265-272.

Patt, T. E., Cole, G. C. \& Hanson, R. S. (1976). Methylobacterium, a new genus of facultative methylotrophic bacteria. International Journal of Systematic Bacteriology 26, 226-229.

Ray, C., Hay, R. E., Carter, H. L. \& Moran, C. P., JR (1985). Mutations that affect utilization of a promoter in stationary-phase Bacillus subtilis. Journal of Bacteriology 163, 610-614.

Ray, C., Igo, M., Shafer, W., Losick, R. \& Moran, C. P., JR (1988). Suppression of ctc promoter mutations in Bacillus subtilis. Journal of Bacteriology 170, 900-907.

SambrooK, J., Fritsch, E. F. \& Maniatis, T. (1989). Molecular Cloning: a Laboratory Manual. Second edition. Cold Spring Harbor, NY: Cold Spring Harbor Laboratory.

Tsuj, K., Tsien, H. C., Hanson, R. S., Depalma, S. R., Scholtz, R. \& LARoche, S. (1990). 16S ribosomal RNA sequence analysis for determination of phylogenetic relationship among methylotrophs. Journal of General Microbiology 136, 1-10.

Windass, J. D., Worsey, M. J., Pioli, E. M., Pioli, D., Barth, P. T., Atherton, K. T., Dart, E. C., Byrom, D., Powell, K. \& Senior, P. J. (1980). Improved conversion of methanol to single-cell protein by Methylophilus methylotrophus. Nature, London 287, 396-401.

Winstanley, C., Morgan, J. A. W., Pickup, R. W., Johns, J. G. \& SAUNDERS, J. R. (1989). Differential regulation of lambda $p_{L}$ and $p_{R}$ promoters by a cI repressor in a broad-host-range thermoregulated plasmid marker system. Applied and Environmental Microbiology $\mathbf{5 5}$, 771-777.

ZHU, Y. S. \& KAPLAN, S. (1985). Effects of light, oxygen, and substrates on steady-state levels of mRNA coding for ribulose-1,5-bisphosphate carboxylase and light-harvesting and reaction center polypeptides in Rhodopseudomonas sphaeroides. Journal of Bacteriology 162, 925-932.

Zukowski, M. M., Gaffney, D. F., SPeck, D., Kauffmann, M., Findel, A., WisecuP, A. \& LecocQ, J.-P. (1983). Chromogenic identification of genetic regulatory signals in Bacillus subtilis based on expression of a cloned Pseudomonas gene. Proceedings of the National Academy of Sciences of the United States of America 80 , 1101-1105. 